Vol.3 No.2 Hal. $44-50$

September 2020
BEST JOURNAI

(Biology Education,Science \& Technology)

Fakultas Keguruan dan IImu Pendidikan
ISSN (Print) : $2614-8064$

ISSN (Online): $2654-4652$

\title{
Pengaruh Penggunaan Smartphone Sebagai Perangkat Pembelajaran Terhadap Pendidikan Karakter Siswa
}

\author{
Ekariana S. Pandia $^{(1)}$, Nurmasyitah ${ }^{(2)}$, Nursamsu ${ }^{(3)}$ \\ Pendidikan Biologi dan Pendidikan Fisika \\ Fakultas Keguruan dan Ilmu Pendidikan \\ Universitas Samudra ${ }^{(1)(2)(3)}$

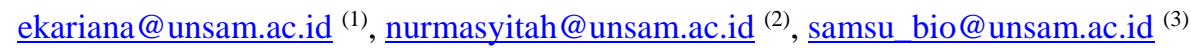

\begin{abstract}
ABSTRAK
Tujuan penelitian adalah untuk mengetahui seberapa besar pengaruh penggunaan smartphone sebagai perangkat pembelajaran terhadap nilai karakter siswa. metode penelitian adalah suatu pendekatan kuantitatif dengan Jenis dari penelitian ini adalah Kausal komparati. Sampel dalam penelitian ini adalah seluruh siswa kelas VIII A yang berjumlah 30 orang dan seluruh siswa kelas VIII B juga berjumlah 30 orang yang terdiri dari kelas eksperimen dan kontrol. Selanjutnya teknik pengumpulan data dilakukan dengan menggunakan angket untuk mengukur pendidikan karakter siswa. Hasil pengujian $\mathrm{t}$ tabel lebih besar dari pada $\mathrm{t}$ hitung yakni $\mathrm{t}_{\text {hitung }}=$ $7.958 \geq\left(\mathrm{t}_{\mathrm{tab}}\right)=2.001$, maka Ho ditolak dan menerima Ha. Dengan demikian, dapat dinyatakan bahwa penggunaan smartphone berpengaruh terhadap pendidikan karakter siswa.
\end{abstract}

Kata Kunci : Smartphone, Perangkat Pembelajaran, Pendidikan Karakter

\begin{abstract}
The purpose of this study was to determine how much influence the use of smartphones as learning devices on student character values. The research method is a quantitative approach. The type of this research is Causal Comparative. The sample in this study were all students of class VIIIA, amounting to 30 people and all students of class VIIIB also numbered 30 people consisting of experimental and control classes. Then the data collection technique is done by using a questionnaire to measure the character education of students. T table test results are greater than $t$ arithmetic namely $t$ count $=7.958 \geq(\mathrm{ttab})=2.001$, then Ho is rejected and accepts Ha. Thus, it can be stated that the use of smartphones affects the character education of students.
\end{abstract}

Keywords : Smartphone, Learning Devices, Character Education 
Pandia E.S, Nurmasyitah, Nursamsu : Pengaruh Penggunaan Smartphone Sebagai Perangkat Pembelajaran Terhadap Pendidikan Karakter Siswa

\section{PENDAHULUAN}

\section{Latar Belakang}

Perkembangan arus pendidikan berbasis teknologi semakin pesat, sehingga mewajibkan bagi dunia pendidikan dapat menguasai tekonologi. Hal ini sudah menjadi kebutuhan dalam kehidupan sehari-hari. Apalagi pada abad 21 ini perkembangan media smartphone, merupakan sebagai alat perangkat untuk belajar berbasis daring. Oleh sebab itulah banyak manfaat dari media smartphone yang dapat dimanfaatkan bagi siswa untuk belajar daring. Hal ini sesuai dengan Menteri Pendidikan dan Kebudayaan Republik Indonesia terkait Surat Edaran Nomor 4 Tahun 2020 tentang Pelaksanaan Kebijakan Pendidikan dalam Masa Darurat Penyebaran Corona Virus Disease (COVID-19). Sistem pembelajaran dilaksanakan melalui perangkat personal computer (PC) atau laptop yang terhubung dengan koneksi jaringan internet. Menurut Riyana (2019:114) pembelajaran daring lebih menekankan pada ketelitian dan kejelian peserta didik dalam menerima dan mengolah informasi yang disajikan secara online. Sistem pembelajaran daring (dalam jaringan) merupakan sistem pembelajaran tanpa tatap muka secara langsung antara guru dan siswa tetapi dilakukan melalui online yang menggunakan jaringan internet. Smartphone adalah alat media pembelajaran bagi siswa untuk pembelajaran daring. Smartphone adalah "sebagai perangkat pembelajaran mobile atau dapat dikatakan handphone dalam menjalankan suatu fitur-fitur modern, sebagai contoh internet dengan cepat mengirim data tanpa adanya berhubungan fisik antara kedua alat (wireles) (Hasjiandito, A. dkk, 2014). Sedana dengan pendapat Istiyanto dan Jazi. E (2013) Smartphone "merupakan salah satu wujud yang merealisasi ubuquitous computing (ubicomp), suatu pembelajaran dengan menggunakan media teknologi yang dapat memungkinkan proses komputasi dapat terintegrasi dengan berbagai aktivitas kegiatan keseharian manusia dengan jangkauannya tidak dibatasi dalam satu wilayah atau suatu scope area. Proses pembelajaran dengan menggunakan media smartphone, dapat memberikan membangun karakter anak, tergantung bagaimana si anak menggunakannya dengan kehidupan sehari - hari. Kita ketahui bahwa membangun karakter siswa dalam proses pembelajaran sangat berperan penting oleh guru. Karakter adalah kualitas atau kekuatan mental atau moral, akhlak atau budi pekerti individu yang merupakan kepribadian khusus yang menjadi pendorong dan penggerak, serta membedakan dengan individu lain ( Furqon. M dan Hidayatullah, 2010). Berkaitan dengan penjelasan tersebut mengenai smartphone dapat mempengaruhi perkembangan pendidikan karakter siswa. Sejak pandemi Covid-19 pihaknya melakukan improvisasi pada seluruh kegiatan belajar mengajar dengan dilaksanakan secara virtual. Maka tepatlah kegiatan penelitian ini dilaksanakan di SMP Negeri 2 Kota Langsa. Hal ini disebabkan bahwa pembelajaran semenjak pandemi Covid19 penyebar maka kebijakan untuk belajar daring melalui perangkat pembelajaran smartphone di implementasikan oleh guru dan siswa di SMP Negeri 2 Langsa. Sebabitulah SMP Negeri 2 Kota Langsa yang menjadi sasaran lokasi penelitian dengan sampel siswa, dengan mengukur karakter siswa pengaruh dalam memanfaatkan smartphone sebagai perangkat pembelajaran dengan belajar daring.

\section{Perumusan Masalah}

Guru sebagai aktor utama dalam dunia pendidikan harus dapat mengikuti perkembangan zaman pada masa pandemi covid-19 ini, sehingga wajib meningkatkan kompetensi. Dengan perangkat pembelajaran dengan menggunakan smartphone, dapat memberikan solusi dalam penelitian yaitu (1) Apakah pengaruh penggunaan smartphone sebagai perangkat pembelajaran terhadap pendidikan karakter siswa di SMP Negeri 2 Kota Langsa; (2) Seberapa besarkah pengaruh penggunaan smartphone sebagai perangkat pembelajaran terhadap pendidikan karakter siswa di SMP Negeri 2 Kota Langsa. 
Pandia E.S, Nurmasyitah, Nursamsu : Pengaruh Penggunaan Smartphone Sebagai Perangkat Pembelajaran Terhadap Pendidikan Karakter Siswa

\section{Tujuan Penelitian}

Beranjak dari perumusan masalah diatas maka tujuan dari penelitian memberikan pengetahuan guru dan siswa pengaruh dari perangkat pembelajaran dengan menggunakan media smartphone. Tim penelitian bertujuan untuk memberikan pengetahuan kepada guru dan siswa sistem pembelajaran daring menggunakan media smartphone dalam menilai pendidikan karakter siswa.

\section{Manfaat Penelitian}

Manfaat yang akan didapat dari penelitian ini adalah mendapatkan hasil nantinya agar guru juga harus mampu menggunakan perangkat pembelajaran smartphone dengan konsep pembelajaran daring, sehingga siswa dapat membentuk karakter pada dirinya dalam mengahadapi tantangan pembelajaran di era revolusi industri 4.0.

\section{METODE PENELITIAN}

Penelitian ini dilaksanakan dengan suatu pendekatan kuantitatif dengan Jenis dari penelitian ini adalah Kausal komparatif. Menurut Arikunto (2010:27) " menjelaskan bahwa penelitian kuantitatif merupakan suatu penelitian yang banyak dituntut menggunakan bentuk angka, mulai dari pengumpulan data, penafsiran data, serta penampilan dan hasilnya. Pelaksanaan penelitian ini juga menggunakan dua variabel yaitu satu variabel bebas dan satu variabel terikat. Variabel bebas dalam penelitian ini adalah Penggunaan Smartphone (X), dan variabel terikat dalam penelitian ini adalah Pendidikan Karakter (Y).

\section{Instrument dan Teknik Pengumpulan Data}

Adapun instrumen yang digunakan dalam penelitian ini adalah non tes. Sedangkan Pengumpulan data dilakukan dengan menggunakan Kuesioner (Angket). Kuesioner adalah teknik pengumpulan data yang dilakukan dengan cara mengajukan seperangkat pertanyaan atau pernyataan tertulis kepada responden untuk dijawabnya. (Sugiono, 2012:199). Untuk menentukan penilaian karakter siswa, dapat di lihat kriteria pada tabel di bawah ini.

Tabel 1. Kriteria Nilai Karakter Siswa

\begin{tabular}{|l|c|l|}
\hline Skala & Interval Skor & Kriteria \\
\hline 4 & $86-100$ & Sangat Baik \\
\hline 3 & $66-85$ & Baik \\
\hline 2 & $46-65$ & Cukup \\
\hline 1 & $0-45$ & Kurang \\
\hline
\end{tabular}

\section{Teknik Analisa Data}

Proses teknik analisa data yang dilakukan dalam penelitian dalam pengujian hipotesis digunakan t-tes (uji-t) dengan rumus sebagai berikut:

$$
\mathrm{t}=\frac{\bar{X}_{1}-\bar{X}_{2}}{\sqrt[s]{\frac{1}{n_{1}}+\frac{1}{n_{2}}}}
$$

Keterangan:

$\mathrm{t} \quad=\mathrm{uji}-\mathrm{t}$

$\bar{X}_{1} \quad=$ nilai rata-rata kelompok eksperimen

$\bar{X}_{2}=$ nilai rata-rata kelompok kontrol

$\mathrm{s} \quad=$ standar deviasi 
Pandia E.S, Nurmasyitah, Nursamsu : Pengaruh Penggunaan Smartphone Sebagai Perangkat Pembelajaran Terhadap Pendidikan Karakter Siswa

$\mathrm{n}_{1} \quad=$ jumlah sampel kelompok eksperimen

$\mathrm{n}_{2} \quad=$ jumlah sampel kelompok kontrol

\section{HASIL DAN PEMBAHASAN}

\section{Hasil Penelitian}

Hasil penelitian ini penilaian pendidikan karakter yang menggunakan media smartphone sebagai perangkat pembelajaran. Penilaian ini dilaksanakan di SMP Negeri 2 Kota Langsa, yang terdiri dari dua kelas VIII sebagai kelas eksprimen dan kontrol. Hasil dari penelitian dilakukan perhitungan pendidikan karakter terdiri dari karakter religius, karakter peduli sosial, karakter disiplin dan karakter tanggung jawab. Untuk mengetahui hasil dari penelitian dapat dilihat pada gambar grafik dibawah ini.

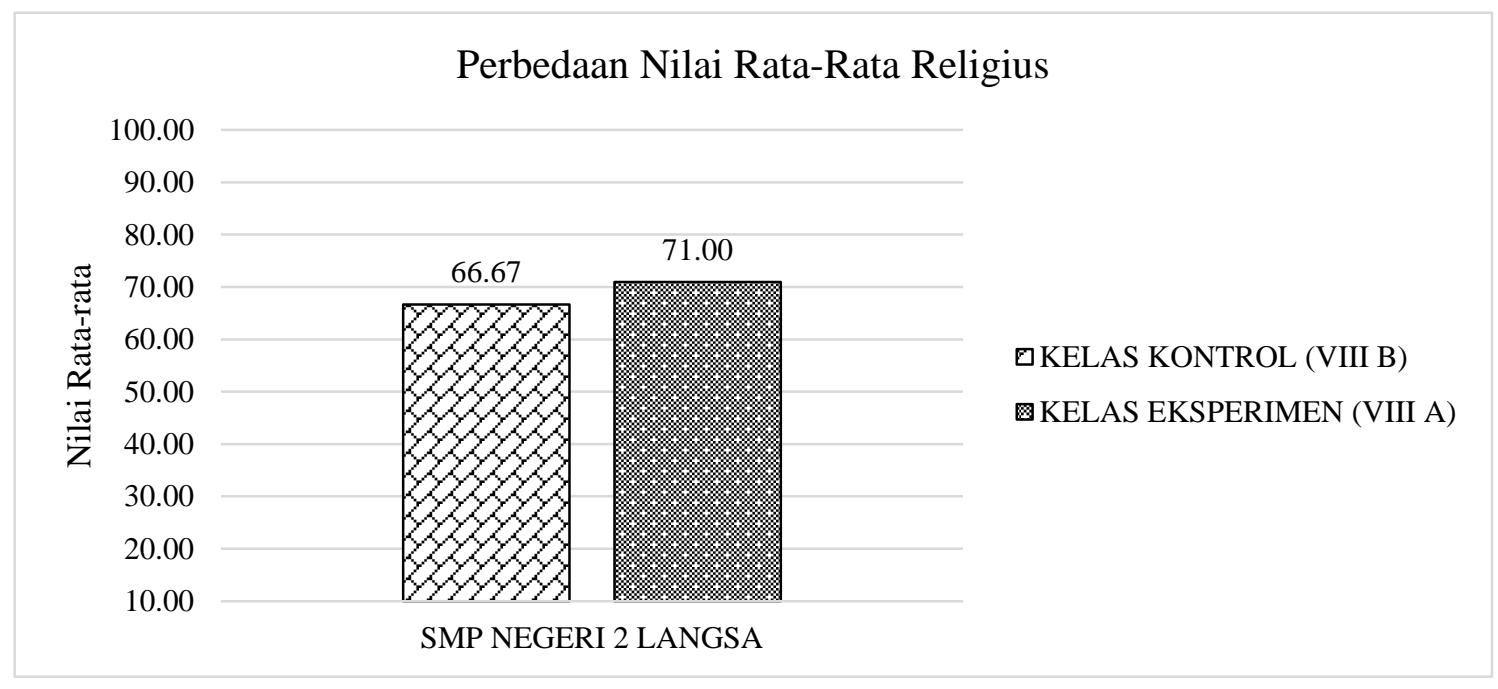

Gambar 1. Nilai Rata - Rata Karakter Religius Kelas Kontrol dan Eksprimen

Hasil dari gambar 1. Menjelaskan bahwa terjadinya perbedaan di antara dua kelas yaitu kelas VIII B merupakan kelas kontrol yang mana nilainya 66,67\% sedangkan kelas VIII A sebagai kelas eksprimen dengan nilai $71,00 \%$. Selanjutnya karakter peduli sosial dapat dilihat pada gambar 2. Dibawah ini.



Gambar 2. Nilai Rata - Rata Karakter Peduli Sosial Kelas Kontrol dan Eksprimen 
Pandia E.S, Nurmasyitah, Nursamsu : Pengaruh Penggunaan Smartphone Sebagai Perangkat Pembelajaran Terhadap Pendidikan Karakter Siswa

Karakter peduli sosial dari kelas VIII B dengan nilai 67,00\% sedangkan kelas VIII A dengan nilai $75,33 \%$. Hasil dari kedua kelas tersebut terdapat perbedaan kontrol dan eksprimen dalam penggunaan media smartphone sebagai perangkat pembelajaran. Berikutnya adalah karakter disiplin sebagai seorang siswa dalam penggunaan media smartphone, hasil nilainya dapat dilihat pada gambar 3 .

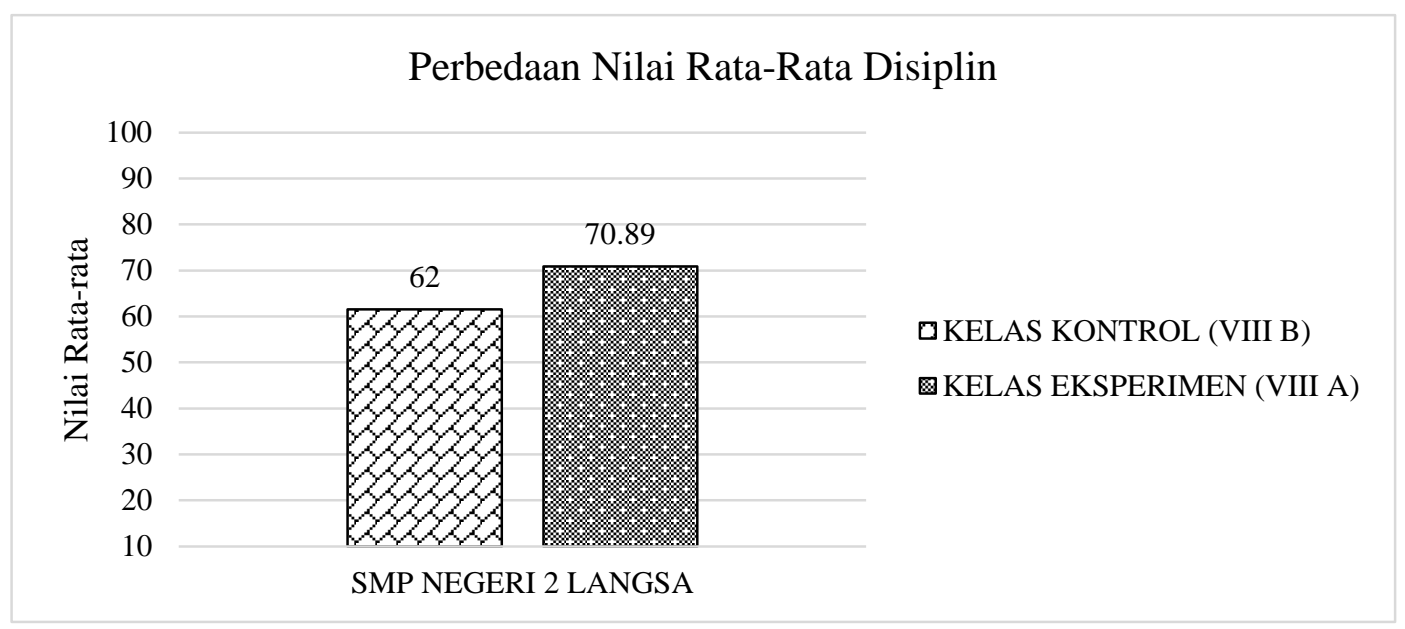

Gambar 3. Nilai Rata - Rata Karakter Disiplin Kelas Kontrol dan Eksprimen

Hasil yang diperoleh pada gambar diatas menjelaskan bahwa terdapat perbedaan dari kedua kelas eksprimen $70,89 \%$ sedangkan kelas kontrol $62,00 \%$ yang menggunakan media smartphone sebagai perangkat pembelajaran. Selanjutnya dilakukan perhitungan karakter tanggung jawab yang dapat dilihat pada gambar 4 .

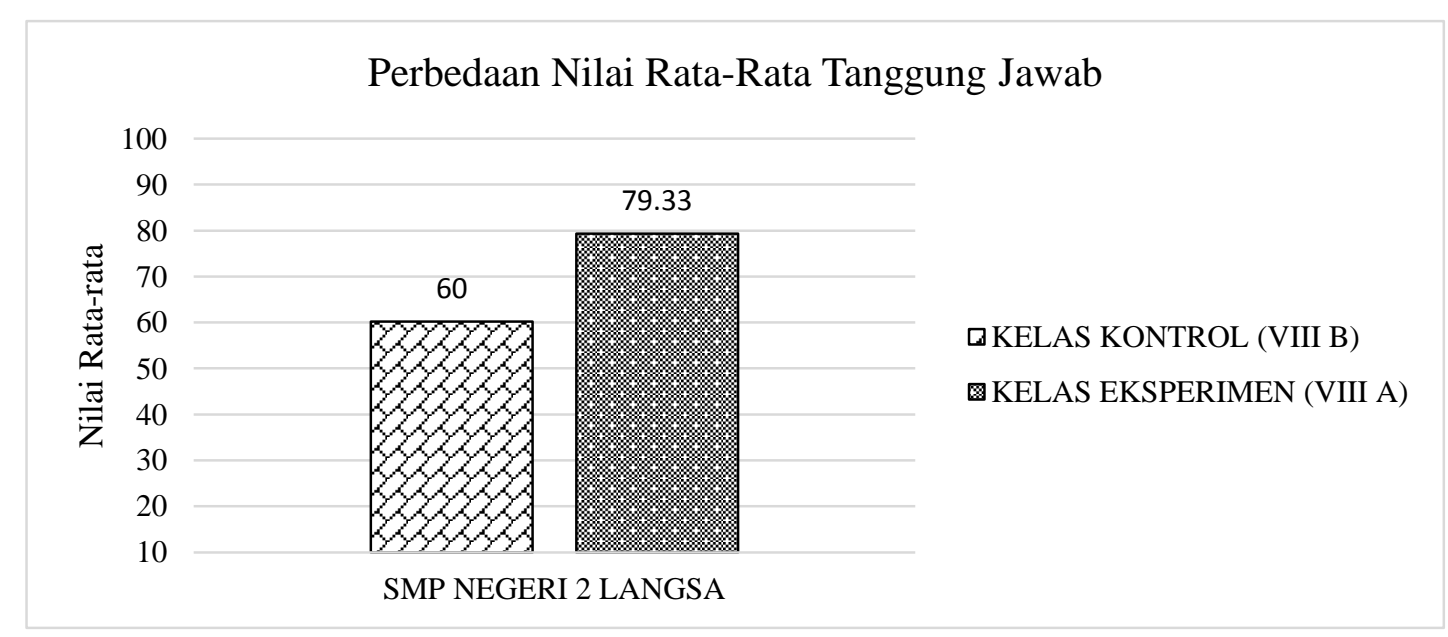

Gambar 4. Nilai Rata - Rata Karakter Disiplin Kelas Kontrol dan Eksprimen

Penjelasan dari kelas VIII B sebagai kontrol dengan nilai 60,00\% dan kelas VIII A yaitu eksprimen dengan nilai $79,33 \%$, makanya kedua kelas tersebut dapat perbedaan dalam menggunakan perangkat pembelajaran smartphone. 
Pandia E.S, Nurmasyitah, Nursamsu : Pengaruh Penggunaan Smartphone Sebagai Perangkat Pembelajaran Terhadap Pendidikan Karakter Siswa

\section{Pembahasan}

Hasil yang diperoleh dari uji hipotesis menunjukkan bahwa terdapat perbedaan dari kedua kelas menggunakan smartphone sebagai perangkat pembelajaran dengan mengukur pendidikan karakter siswa yang dilaksanakan di SMP Negeri 2 Kota Langsa. Hasil dari kedua kelas tersebut pada kita lihat pada tabel berikut.

Tabel 1. Perbedaan Nilai Rata - Rata Kelas VIII A dan Kelas VIII B

\begin{tabular}{|c|c|c|c|c|c|}
\hline \multirow[b]{2}{*}{ Kelas } & & \multicolumn{2}{|c|}{$\begin{array}{l}\text { Levene's Test for Equality } \\
\text { of Variances }\end{array}$} & \multicolumn{2}{|c|}{$\begin{array}{l}\text { t-test for Equality of } \\
\text { Means }\end{array}$} \\
\hline & & $F$ & Sig. & $t$ & Df \\
\hline Hasil & $\begin{array}{l}\text { Equal variances assumed } \\
\text { Equal variances not assumed }\end{array}$ & ,415 &, 522 & $\begin{array}{l}-7,958 \\
-7,958 \\
\end{array}$ & $\begin{array}{l}58 \\
56,383 \\
\end{array}$ \\
\hline
\end{tabular}

Berdasarkan gambar diatas menjelaskan bahwa terdapat pengaruh penggunaan smartphone sebagai perangkat pembelajaran terhadap pendidikan karakter siswa. Hal ini kita lihat nilai dari kedua kelas tersebut dengan perhitungan dengan hasil pengujian $t$ tabel lebih besar dari pada $t$ hitung yakni thitung $=7.958 \geq(\mathrm{ttab})=2.001$, maka Ho ditolak dan menerima Ha. Dengan demikian, dapat dinyatakan bahwa penggunaan smartphone berpengaruh terhadap pendidikan karakter siswa. Berhubungan dengan hasil dari penelitian ini, maka sedana dengan hasil penelitian dari Chatur Septyawan (2019) menyatakan pengetahuan sebesar $60,5 \%$, pengaruh penggunaan smartphone terhadap sikap sebesar $48,7 \%$. Ada pengaruh penggunaan media smartphone sebagai sumber belajar terhadap prestasi akademik studi fiqh melalui motivasi belajar mahasiswa PAI UIN Maliki Malang (Musyrif Kamal J. Haq, 2017). Hasil penelitian ini sejalan dengan hasil penelitian yang teliti oleh Gardenia Augusta (2018) yang menegaskan bahwa penggunaan smartphone pada mahasiswa memiliki pengaruh terhadap motivasi belajar mereka sebesar $4.3 \%$ dan sisanya 95.7 dipengaruhi variabel lain dengan tingkat signifikansi sebesar 0,037. Ming Hun Lin, dkk (2017) menegaskan bahwa pembelajaran digital memberikan pengaruh yang positif terhadap motivasi belajar siswa dan juga dapat meningkatkan hasil belajar siswa SD. Ketergantungan siswa pada smartphone secara langsung membuat mereka malas belajar. Pada dasarnya dalam belajar sangat diperlukan adanya motivasi (Habibi, dkk. 2018).

\section{KESIMPULAN}

Hasil pengujian $t$ tabel lebih besar dari pada t hitung yakni thitung $=7.958 \geq($ ttab $)=2.001$, maka Ho ditolak dan menerima Ha, maka dapat dikatakan adanya pengaruh nilai karakter siswa dari kedua kelas kontrol dan eksperimen.

\section{DAFTAR PUSTAKA}

Arikunto, Suharsimi. (2010). Prosedur Penelitian suatu Pendekatan Praktik. Jakarta: Rineka Cipta.

Augusta, Garedina. 2018. "Skripsi: Pengaruh Penggunaan Smartphone Terhadap Prestasi Belajar Mahasiswa melalui motivasi belajar Mahasiswa." Universitas Sanata Dharma, Program Studi Pendidikan Ekonomi, Yogyakarta.

Budiono, Persepsi Dan Harapan Penggunaan Terhadap Kualitas Layanan Data Pada Smartphone Di Jakarta, (Jurnal Telekomunikasi, Vol. 11 No 2, 2013) Hlm. 93. 
Pandia E.S, Nurmasyitah, Nursamsu : Pengaruh Penggunaan Smartphone Sebagai Perangkat Pembelajaran Terhadap Pendidikan Karakter Siswa

Chatur Septyawan (2019). Pengaruh Penggunaan Smartphone Terhadap Perilaku Komunikasi Siswa Kelas Ix Smpn 3 Sungguminasa. Skripsi. Jurusan Ilmu Komunikasi Fakultas Dakwah Dan Komunikasi Uin Alauddin Makassar.

Furqon. M. Hidayatullah. 2010. Pendidikan karakter: Membangun Peradaban Bangsa: Yuma Pustaka. Surakarta.

Hasjiandito, A., Haryono, \& Djunaedi. 2014. Pengembangan Model Pembelajaran Blended Learning Berbasis Proyek pada Mata Kuliah Media Pembelajaran. Innovative Journal of Curriculum and Educational Technology 3(2).

Habibi, M., Chandra, C., Mahyuddin, R., \& Hendri, S. (2018). Validity of Teaching Materials for Writing Poetry Based on Creative Techniques in Elementary Schools. Mimbar Sekolah Dasar, 5(3), 145-154. ttps://doi.org/10.17509/mimbar- sd. v5i3.14501.

Istiyanto, Jazi Eko.(2013). Pemrograman Smartphone Menggunakan SDK Android dan Hacking Android.Yogyakarta: Graha Ilmu.

Ming-Hun Lin., Huang-Cheng Chen., dan Kuang-Sheng Liu. 2017. "A Study of the Effects of Digital Learning on Learning Motivation and Learning Outcome," dalam EURASIA Journalof Mathematics Science and Technology Education, ISSN:1305-8223 (online), 201713 (7): 3553-3564.

Menteri Pendidikan. (2020). Surat Edaran Nomor 3 Tahun 2020 Tentang Pelaksanaan Pendidikan dalam Masa Darurat CoronaVirus (COVID-19).

Musyrif Kamal J. Haq. 2017. Pengaruh Penggunaan Media Smartphone Sebagai Sumber Belajar Terhadap Motivasi Belajar Dan Prestasi Akademik Mata Kuliah Studi Fiqh Mahasiswa Jurusan Pendidikan Agama Islam Uin Maliki Malang. Tesis. Program Magister Pendidikan Agama Islam Pascasarja Universitas Islam Negeri Maulana Malik Ibrahim Malang.

Peraturan Menteri Pendidikan dan Kebudayaan Republik Indonesia Nomor 23 Tahun 2015. Jakarta: Permendikbud.

Riyana, C. (2019). Produksi Bahan Pembelajar Berbasis Online. Universitas Terbuka.

Sari, P. (2015). Memotivasi Belajar dengan Menggunakan E-Learning. Jurnal Ummul Quro, 6(2), 20 35.http://ejournal.kopertais4.or.id/index.php/qur a/issue/view/531

Sugiyono. 2012. Metode Penelitian Pendidikan Pendekatan Kuantitatif, Kualitatif dan $R \& D$. Bandung: Alfabeta.

Sudjana, N. (1989). Metode Statistika. Bandung : Tarsito.

\begin{tabular}{|l|l|l|l|}
\hline Accepted Date & Revised Date & Decided Date & Accepted to Publish \\
\hline 29 Juli 2020 & 04 Agustus 2020 & 07 Agustus 2020 & Ya \\
\hline
\end{tabular}

